Check for updates

Cite this: RSC Adv., 2017, 7, 37478

\title{
Phthalide derivatives from Ligusticum chuanxiong $\dagger$
}

\author{
Xu Zhang, Bing Han, Zi-Ming Feng, Ya-Nan Yang, (D) Jian-Shuang Jiang \\ and Pei-Cheng Zhang*
}

Eleven new phthalide derivatives (1-11) have been isolated from the rhizome of Ligusticum chuanxiong. In particular, 1 and 2 contain a mercaptopropionic acid moiety in the phthalide derivatives. All the structures, including their absolute configurations, were determined by UV, IR, HRESIMS, $1 D$ and 2D NMR spectroscopic measurements, and by a comparison of the experimental and calculated electronic circular dichroism (ECD) spectra. Results of a bioassay showed that compound 4 has a moderate neuroprotective activity on human neuroblastoma $\mathrm{SH}-\mathrm{SY} 5 \mathrm{Y}$ cell injury induced by $\mathrm{H}_{2} \mathrm{O}_{2}$ and oxygen glucose deprivation (OGD).

Received 19th June 2017

Accepted 25th July 2017

DOI: 10.1039/c7ra06813a

rsc.li/rsc-advances

induced by $\mathrm{H}_{2} \mathrm{O}_{2}$ and OGD were evaluated at a concentration of

\section{Introduction}

The rhizome of Ligusticum chuanxiong Hort. (syn. Ligusticum striatum DC.) (Apiaceae), named Chuanxiong in traditional Chinese medicine, is commonly used for treating atherosclerosis, cardiovascular disease, anemia and hypertension. ${ }^{1}$ This plant is mainly distributed in the Sichuan province but also in Yunnan, Guizhou, and Guangxi provinces in China. So far, the phenolic acids, alkaloids, and phthalides ${ }^{2-16}$ contained in it have been investigated. Among these compounds, tetramethylpyrazine and ferulic acid were considered to be the active constituents. ${ }^{17-24}$ The phthalides from L. chuanxiong have attracted particular attention due to their vasodilative, ${ }^{17,25,26}$ neuroprotective, ${ }^{27}$ antiproliferative, ${ }^{28,29}$ anti-inflammatory ${ }^{24}$ and antibacterial effects. ${ }^{30}$ In particular, $Z$-ligustilide, a phthalide isolated from $L$. chuanxiong, displays various pharmacological activities including neuroprotective, anti-inflammatory, antiproliferative and vasorelaxation effects. ${ }^{31-34}$ It is considered a major bioactive compound relevant to the therapeutic effects and has attracted great interest in recent years. Overall, more than 40 phthalide lactones have been obtained from the rhizome of $L$. chuanxiong, ${ }^{35,36}$ but most of them were isolated from the liposoluble fraction. In consideration of the bioavailability in vivo, the phthalide derivatives from the water-soluble extract of this plant deserve to be the primary focus of further studies. In the course of our study, eleven new phthalide derivatives (1-11) have been isolated and their structures were elucidated by various spectroscopic methods (Fig. 1). Subsequently, their neuroprotective activities on SH-SY5Y cell injury

State Key Laboratory of Bioactive Substance and Function of Natural Medicines, Institute of Materia Medica, Chinese Academy of Medical Sciences, Peking Union Medical College, Beijing 100050, People's Republic of China. E-mail: pczhang@ imm.ac.cn

† Electronic supplementary information (ESI) available: 1D NMR, 2D NMR HRMS, IR, and ECD spectra. See DOI: 10.1039/c7ra06813a $10 \mu \mathrm{M}$.

\section{Results and discussion}

Compound 1 was obtained as a white amorphous powder, and its molecular formula was established as $\mathrm{C}_{15} \mathrm{H}_{20} \mathrm{O}_{7} \mathrm{~S}$ by HRESIMS at $m / z 345.0999[\mathrm{M}+\mathrm{H}]^{+}$(calcd 345.1003). The IR spectrum peaks at $3387 \mathrm{~cm}^{-1}, 1741 \mathrm{~cm}^{-1}$ and $1682 \mathrm{~cm}^{-1}$ suggest the presence of hydroxy, $\gamma$-lactone and diene groups, respectively. In the ${ }^{1} \mathrm{H}$ NMR spectra (Table 1$)$, a double bond at $\delta_{\mathrm{H}} 5.48(1 \mathrm{H}, \mathrm{t}$, $J=7.5 \mathrm{~Hz}, \mathrm{H}-8)$, six methylene resonances at $\delta_{\mathrm{H}} 2.43(2 \mathrm{H}, \mathrm{m}, \mathrm{H}-$ 4), 1.81 (2H, m, H-5), $2.31(2 \mathrm{H}, \mathrm{q}, J=7.5 \mathrm{~Hz}, \mathrm{H}-9), 1.56(2 \mathrm{H}, \mathrm{m}$, $\mathrm{H}-10), 3.41(2 \mathrm{H}, \mathrm{t}, J=6.0 \mathrm{~Hz}, \mathrm{H}-11), 2.89(1 \mathrm{H}, \mathrm{dd}, J=7.0$, $\left.13.5 \mathrm{~Hz}, \mathrm{H}-1^{\prime} \mathrm{a}\right), 3.02\left(1 \mathrm{H}, \mathrm{dd}, J=4.5,13.5 \mathrm{~Hz}, \mathrm{H}-1^{\prime} \mathrm{b}\right)$, one methine resonance at $\delta_{\mathrm{H}} 3.50(1 \mathrm{H}$, brs, $\mathrm{H}-7)$, and two oxygenmethine resonances at $\delta_{\mathrm{H}} 4.10(1 \mathrm{H}$, brs, $\mathrm{H}-6)$ and $4.17(1 \mathrm{H}$, $\left.\mathrm{dd}, J=4.5,7.0 \mathrm{~Hz}, \mathrm{H}-2^{\prime}\right)$ were presented. The ${ }^{13} \mathrm{C}$ NMR spectrum (Table 1) shows 15 carbon resonances, including two carboxyl carbons at $\delta_{\mathrm{C}} 173.9\left(\mathrm{C}-3^{\prime}\right)$ and $168.1(\mathrm{C}-1)$, four olefinic carbons, five methylene carbons, a methine carbon resonance at $\delta_{\mathrm{C}} 41.8$ (C-7), an oxygen-methylene carbon resonance at $\delta_{\mathrm{C}} 60.2(\mathrm{C}-11)$, and two oxygen-methine resonances at $\delta_{\mathrm{C}} 67.5$ (C-6) and 70.4 (C-2'). In the HMBC experiment (Fig. 2), the correlations from $\mathrm{H}-8\left(\delta_{\mathrm{H}} 5.48\right)$ to $\mathrm{C}-3\left(\delta_{\mathrm{C}} 147.7\right)$ and $\mathrm{C}-3 \mathrm{a}\left(\delta_{\mathrm{C}} 151.6\right)$ suggest the existence of a 1,3-butadiene moiety. Furthermore, it was confirmed to be connected to a 3-hydroxypropyl on the basis of the correlations of the ${ }^{1} \mathrm{H}-{ }^{1} \mathrm{H}$ COSY experiment (Fig. 2), including those between $\mathrm{H}-8$ and $\mathrm{H}-9, \mathrm{H}-9$ and $\mathrm{H}-10$, and $\mathrm{H}-10$ and $\mathrm{H}-11$. In addition, the ${ }^{1} \mathrm{H}-{ }^{1} \mathrm{H}$ COSY correlations from $\mathrm{H}-4$ to $\mathrm{H}-5$, from $\mathrm{H}-5$ to $\mathrm{H}-6$, and from $\mathrm{H}-6$ to $\mathrm{H}-7$ together with the HMBC correlations from H-6 $\left(\delta_{\mathrm{H}} 4.10\right)$ to C-7a, from $\mathrm{H}-7\left(\delta_{\mathrm{H}}\right.$ $3.50)$ to C-7a and C-3a, from $\mathrm{H}-5\left(\delta_{\mathrm{H}} 1.81\right)$ to $\mathrm{C}-3 \mathrm{a}$, and from $\mathrm{H}-4$ $\left(\delta_{\mathrm{H}} 2.43\right)$ to $\mathrm{C}-3 \mathrm{a}$ and $\mathrm{C}-7 \mathrm{a}$ indicate the existence of a cyclohexene moiety. The 2-carboxyl-2-hydroxy-ethylthio moiety on position C-7 was confirmed by the ${ }^{1} \mathrm{H}^{-}{ }^{1} \mathrm{H}$ COSY correlations 


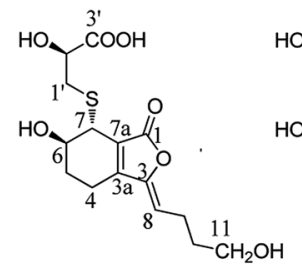

1

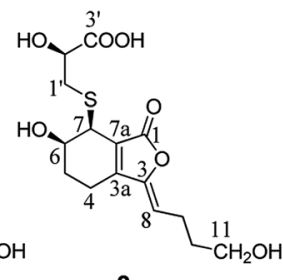

2

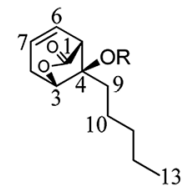

$\begin{array}{ll}3 & R=G 2 \\ \text { 3a } & R=H\end{array}$

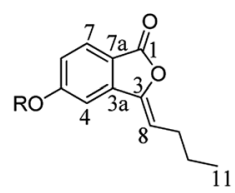

$4 R=G 1$

$5 \mathrm{R}=\mathrm{G} 2$

$6 \mathrm{R}=\mathrm{G} 3$

$7 \mathrm{R}=\mathrm{G} 4$

$8 \mathrm{R}=\mathrm{G} 5$

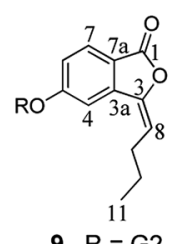

$9 \mathrm{R}=\mathrm{G} 2$

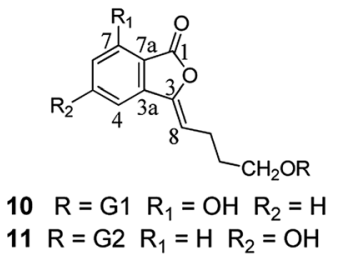<smiles>OCC1OC(=[V])C(O)C(O)C1O</smiles>

G1<smiles>CC1[C]OC(CO[C@H]2OCC2(O)CO)C1O</smiles>

G2

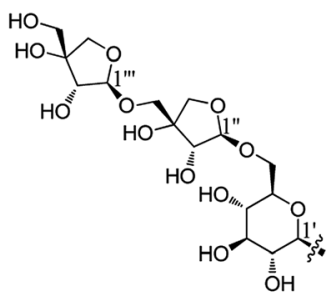

G3

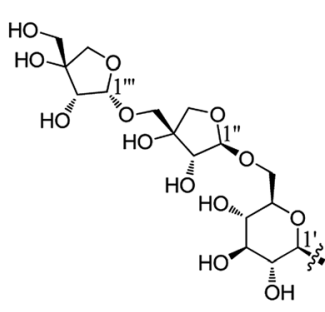

G4

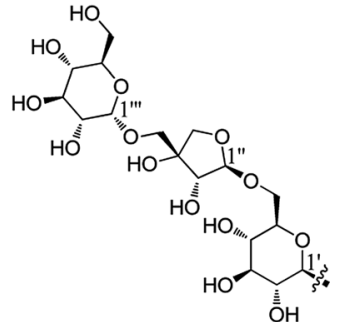

G5

Fig. 1 Chemical structures of 1-11.

Table $1{ }^{1} \mathrm{H}$ NMR $\left(500 \mathrm{MHz}\right.$ ) and ${ }^{13} \mathrm{C}$ NMR (125 MHz) data of compounds $1-3$ in DMSO- $d_{6}$

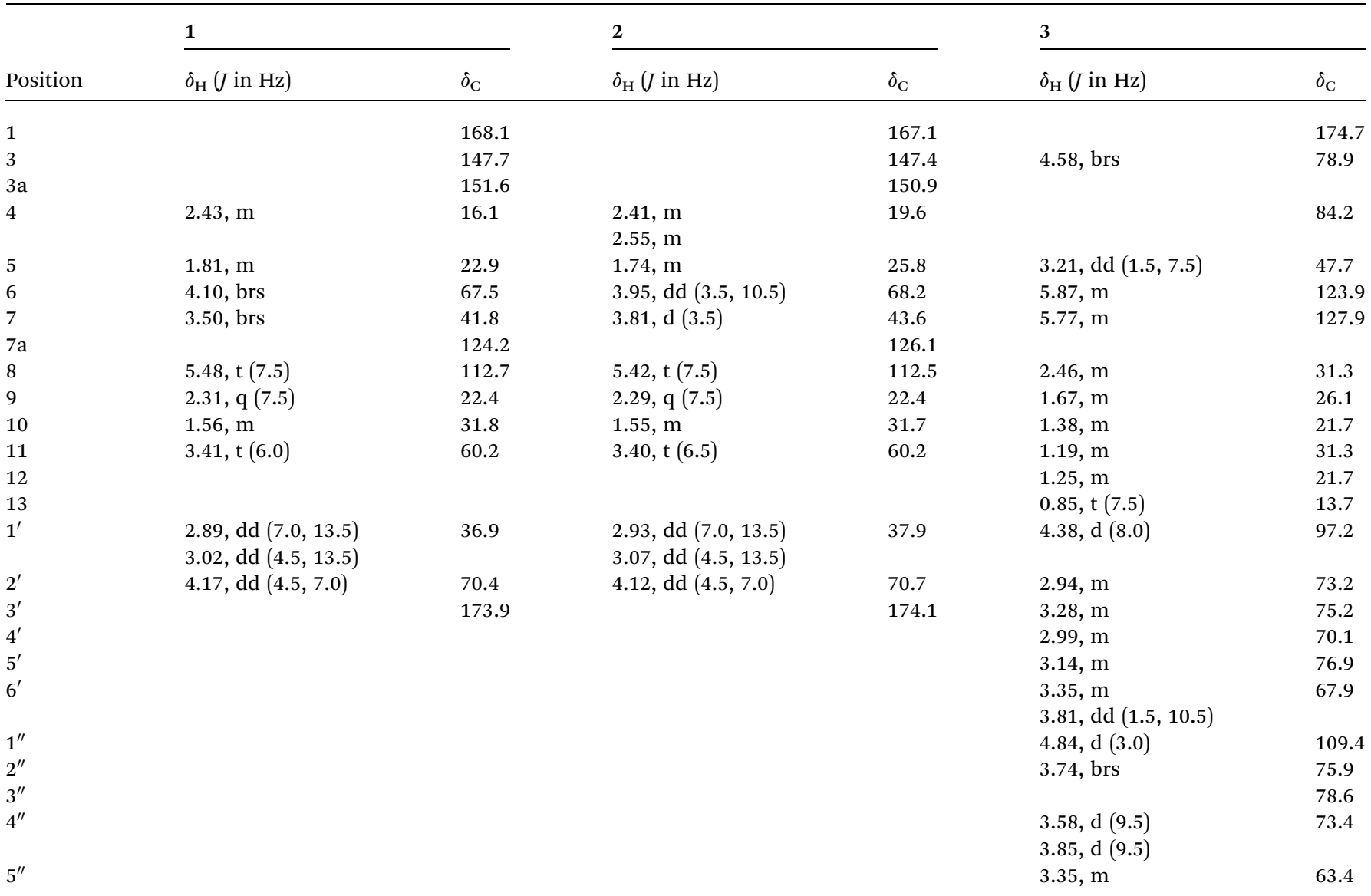

from $\mathrm{H}-1^{\prime}\left(\delta_{\mathrm{H}} 2.89,3.02\right)$ to $\mathrm{H}-2^{\prime}\left(\delta_{\mathrm{H}} 4.17\right)$ and the $\mathrm{HMBC}$ correlations from $\mathrm{H}-1^{\prime}$ and $\mathrm{H}-2^{\prime}$ to the carbonyl carbon at $\delta_{\mathrm{C}}$ 173.9 and from $\mathrm{H}-7$ to $\mathrm{C}-1^{\prime}$ at $\delta_{\mathrm{C}} 36.9$ in consideration of the changes of the chemical shifts of $\mathrm{C}-7$ and $\mathrm{C}-\mathbf{1}^{\prime}$. The HMBC correlation from $\mathrm{H}-7$ to the carbonyl at $\delta_{\mathrm{C}} 168.1$ indicates that C7a connected with the carbonyl. Thus, the planar structure was 

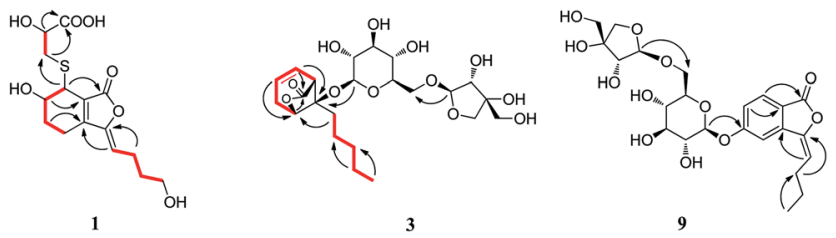

HMBC $\frown{ }^{1}{ }^{1}{ }^{1} \mathrm{H} \operatorname{COSY}-$

Fig. 2 Key $\mathrm{HMBC}$ and ${ }^{1} \mathrm{H}-{ }^{1} \mathrm{H}$ COSY correlations of 1,3 and 9.

determined to be 6-hydroxy-7-(2-carboxyl-2-hydroxy-ethylthio)3-(4-hydroxybutylidene)-4,5,6,7-tetrahydrophthalide. The absolute configuration of C-2 ${ }^{\prime}$ in $\mathbf{1}$ was established by a dimolybdenum tetraacetate $\left[\mathrm{Mo}_{2}(\mathrm{AcO})_{4}\right]$-induced circular dichroism procedure. ${ }^{37}$ The diagnostic Cotton effect approximately $344.5 \mathrm{~nm}$ was negative, so the absolute configuration of C-2' in 1 was assigned as $S$. In the ROESY spectra (Fig. 3), the correlation between $\mathrm{H}-8$ and $\mathrm{H}-4$ proved the $Z$-configuration of the double bond on position C-3, and the correlation between $\mathrm{H}-6$ and $\mathrm{H}-\mathrm{1}^{\prime}$ suggested that their relative configuration was trans. Their absolute configuration was determined by comparing the experimental and calculated ECD data based on the timedependent density functional theory (TD-DFT) method at the B3LYP/6-31+G (d,p) level. Considering that the variations in the side chain resulted in too many conformations and had little effect on the CD spectrum of the tetrahydrophthalide core in $\mathbf{1}$, the selected conformers 1Ja $(6 S, 7 S)$ and $\mathbf{1 J b}(6 R, 7 R)$ were calculated after optimization (Fig. 4). A comparison of the theoretically calculated and experimental ECD curves (Fig. 5) permitted the assignment of the absolute configuration of $\mathbf{1}$ as $6 R, 7 R$. Finally, the structure of 1 was determined to be $(3 Z, 3 \mathrm{a} E)$ (6R,7R,2'S)-6-hydroxy-7-(2-carboxyl-2-hydroxyethylthio)-3-(4hydroxybutylidene)-4,5,6,7-tetrahydrophthalide, named thiosenkyunolide A.

The HRESIMS of $\mathbf{2}$ gave the same molecular formula as $\mathbf{1}$, $\mathrm{C}_{15} \mathrm{H}_{20} \mathrm{O}_{7} \mathrm{~S}$, based on the $[\mathrm{M}+\mathrm{Na}]^{+}$ion peak at $\mathrm{m} / \mathrm{z} 367.0827$ (calcd 367.0822). The ${ }^{1} \mathrm{H}$ and ${ }^{13} \mathrm{C}$ NMR spectra of 2 (Table 1) were closely comparable to those of $\mathbf{1}$, with the minor differences occurring in the signals in the cyclohexene moiety, that is, the ${ }^{13} \mathrm{C}$ NMR data were shifted downfield, except that of C-3a (Table 1). Further 2D NMR analysis, including HSQC, HMBC, and ${ }^{1} \mathrm{H}^{1}{ }^{1} \mathrm{H}$ COSY experiments, confirmed that compound 2 was the optical isomer of compound $\mathbf{1}$. Using the same method, the absolute configuration of $\mathrm{C}^{\prime} 2^{\prime}$ in 2 was established as $S$ by a dimolybdenum tetraacetate $\left[\mathrm{Mo}_{2}(\mathrm{AcO})_{4}\right]$-induced circular

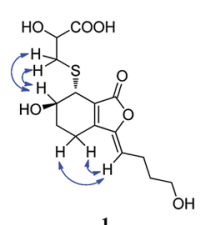

1

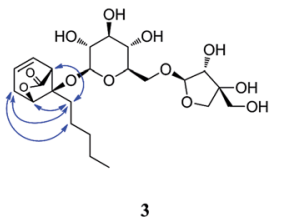

ROESY

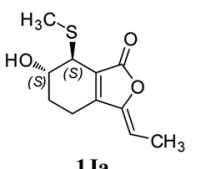

$1 \mathrm{Ja}$
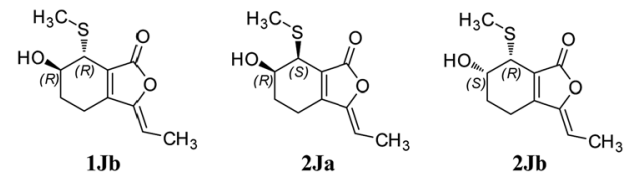

Fig. 4 The structures of $1 \mathrm{Ja}, 1 \mathrm{Jb}, 2 \mathrm{Ja}$ and $2 \mathrm{Jb}$. dichroism procedure, ${ }^{37}$ whose diagnostic Cotton effect at approximately $345 \mathrm{~nm}$ was also negative. In the ROESY spectra, the correlation between $\mathrm{H}-8$ and $\mathrm{H}-4$ proved the $Z$-configuration of the double bond at position $\mathrm{C}-3$, but the correlation between $\mathrm{H}-6$ and $\mathrm{H}-\mathbf{1}^{\prime}$ was not observed in $\mathbf{2}$ compared with $\mathbf{1}$, which suggested that the relative configuration between them was cis. The absolute configurations of $6 R, 7 S$ were further confirmed by a comparison of the experimental ECD spectrum and calculated ECD data using the aforementioned methods (Fig. 5). Thus, the structure of $\mathbf{2}$ was determined to be $(3 Z, 3 a E)-\left(6 R, 7 S, 2^{\prime} S\right)$-6-hydroxy-7-(2-carboxyl-2-hydroxyethylthio)-3(4-hydroxylbutylidene)-4,5,6,7-tetrahydrophthalide, named thiosenkyunolide B.

Compound 3 was obtained as a white amorphous powder. Its molecular formula was identified as $\mathrm{C}_{23} \mathrm{H}_{36} \mathrm{O}_{12}(\mathrm{~m} / z \mathbf{z} 503.2148$ $[\mathrm{M}-\mathrm{H}]^{-}$) by negative HRESIMS. The IR absorptions at 3336 $\mathrm{cm}^{-1}, 1774 \mathrm{~cm}^{-1}$ and $1049 \mathrm{~cm}^{-1}$ represented a hydroxyl group, carbonyl group and alkenyl group, respectively. The ${ }^{1} \mathrm{H}$ NMR and ${ }^{13} \mathrm{C}$ NMR spectra (Table 1) of 3 displayed an amyl side chain that produced a methyl resonances $\left[\delta_{\mathrm{H}} 0.85(3 \mathrm{H}, \mathrm{t}, J=7.5 \mathrm{~Hz}, \mathrm{H}-\right.$ $\left.13) ; \delta_{\mathrm{C}} 13.7\right]$ and four methylene resonances $\left[\delta_{\mathrm{H}} 1.25(2 \mathrm{H}, \mathrm{m}, \mathrm{H}-\right.$ 12), $1.19(2 \mathrm{H}, \mathrm{m}, \mathrm{H}-11), 1.38(2 \mathrm{H}, \mathrm{m}, \mathrm{H}-10), 1.67(2 \mathrm{H}, \mathrm{m}, \mathrm{H}-9) ; \delta_{\mathrm{C}}$ $21.7,31.3,21.7,26.1$, respectively]; two olefinic $\left[\delta_{\mathrm{H}} 5.77(1 \mathrm{H}, \mathrm{m}\right.$, $\left.\mathrm{H}-7), 5.87(1 \mathrm{H}, \mathrm{m}, \mathrm{H}-6) ; \delta_{\mathrm{C}} 127.9,123.9\right]$; an oxymethine $\left[\delta_{\mathrm{H}} 4.58\right.$ $\left.(1 \mathrm{H}, \mathrm{brs}, \mathrm{H}-3) ; \delta_{\mathrm{C}} 78.9\right]$ and a methine $\left[\delta_{\mathrm{H}} 3.21(1 \mathrm{H}, \mathrm{dd}, J=1.5\right.$, $\left.7.5 \mathrm{~Hz}, \mathrm{H}-5) ; \delta_{\mathrm{C}} 47.7\right]$; and one methylene [2.46 (2H, m, H-8); $\delta_{\mathrm{C}}$ 31.3]. Furthermore, a carbonyl carbon at $\delta_{\mathrm{C}} 174.7$ (C-1) and a quaternary carbon $\delta_{\mathrm{C}} 84.2(\mathrm{C}-4)$ were observed. The presence of two anomeric protons at $\delta_{\mathrm{H}} 4.38\left(1 \mathrm{H}, \mathrm{d}, J=8.0 \mathrm{~Hz}, \mathrm{H}-1^{\prime}\right)$ and $4.84\left(1 \mathrm{H}, \mathrm{d}, J=3.0 \mathrm{~Hz}, \mathrm{H}-1^{\prime \prime}\right)$ and eleven carbons proved that compound 3 contained two sugar moieties. Comparison of the NMR data of 3 with those of the known compound ligusticoside $\mathrm{A}^{16}$ suggested that these two compounds shared a similar skeleton except sugar moieties. In the HMBC spectrum, the correlations $\mathrm{H}-\mathbf{1}^{\prime} / \mathrm{C}-4$ and $\mathrm{H}-\mathbf{1}^{\prime \prime} / \mathrm{C}-\mathrm{6}^{\prime}$ proved that the glucose moiety was attached at C-4 and the pentose was attached at the C-6' ${ }^{\prime}$ of glucose (Fig. 2). The configurations of the apiose and glucose were determined to be D-configurations by GC analysis after acidic hydrolysis and chiral derivatization (retention times at $18.26,29.32 \mathrm{~min})$. The $\beta$-anomeric configurations were deduced on the basis of their coupling constants (Glc: $J=8.0$ $\mathrm{Hz}$; Api: $J=3.0 \mathrm{~Hz}$ ). In the ROESY spectrum of 3, the correlations of $\mathrm{H}-8 / \mathrm{H}-9, \mathrm{H}-8 / \mathrm{H}-10, \mathrm{H}-5 / \mathrm{H}-9, \mathrm{H}-5 / \mathrm{H}-10$ and $\mathrm{H}-3 / \mathrm{H}-9$ indicated that $\mathrm{H}-3, \mathrm{H}-5$ and amyl chain were located on the same side (Fig. 3).

The absolute configuration of $\mathbf{3}$ was determined by comparing the experimental and calculated ECD data based on the TD-DFT method at the B3LYP/6-31+G (d,p) level. Considering the numerous conformations of sugar, we used the aglycone 3a

Fig. 3 Key ROESY correlations of 1 and 3 . 

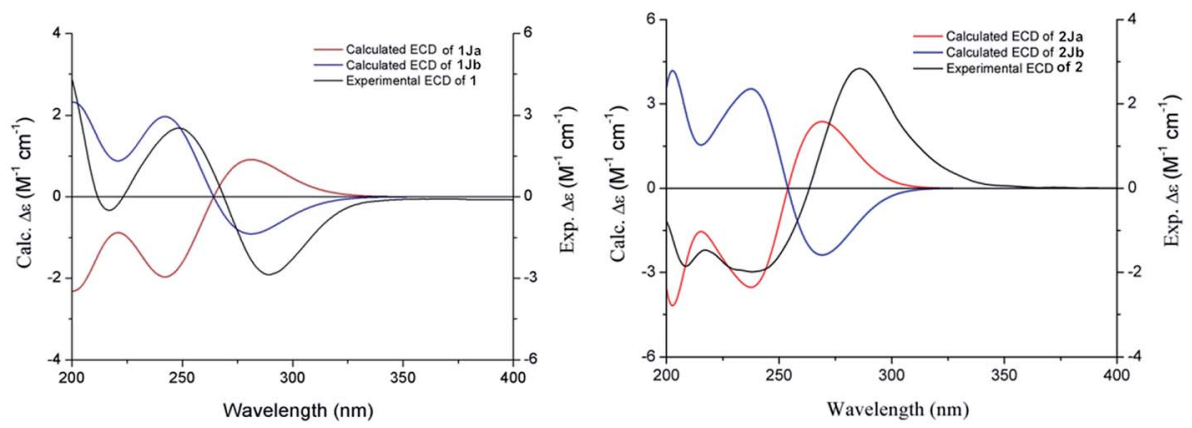

Fig. 5 Experimental ECD and calculated ECD spectrum of 1 and 2 in $\mathrm{MeOH}$.

which was obtained from the acidic hydrolysis for ECD calculations. Through all wavelengths, the absolute configuration of $3 S, 4 R, 5 R$ was confirmed by matching the calculated spectrum with the experimental ECD data (Fig. 6). Thus, the structure of 3 was confirmed and named ligusticoside B.

Compound $\mathbf{4}$ was obtained as a white amorphous powder. The positive HRESIMS gave the $[\mathrm{M}+\mathrm{H}]^{+}$ion peak at $\mathrm{m} / \mathrm{z}$ 367.1399 , in accordance with an empirical molecular formula of $\mathrm{C}_{18} \mathrm{H}_{22} \mathrm{O}_{8}$. The ${ }^{1} \mathrm{H}$ NMR spectrum (Table 2) of 4 presented a methyl resonance at $\delta_{\mathrm{H}} 0.95(3 \mathrm{H}, \mathrm{t}, J=7.5 \mathrm{~Hz}, \mathrm{H}-11)$, two methylene resonances at $\delta_{\mathrm{H}} 1.51(2 \mathrm{H}, \mathrm{m}, \mathrm{H}-10)$ and $2.36(2 \mathrm{H}, \mathrm{q}$, $J=7.5 \mathrm{~Hz}, \mathrm{H}-9)$ and an olefinic proton at $\delta_{\mathrm{H}} 5.96(1 \mathrm{H}, \mathrm{t}$, $J=8.0 \mathrm{~Hz}, \mathrm{H}-8)$. An ABX system at $\delta_{\mathrm{H}} 7.80(1 \mathrm{H}, \mathrm{d}, J=8.5 \mathrm{~Hz}, \mathrm{H}-7)$, $7.20(1 \mathrm{H}, \mathrm{dd}, J=8.5,2.0 \mathrm{~Hz}, \mathrm{H}-6)$ and $7.59(1 \mathrm{H}, \mathrm{d}, J=2.0 \mathrm{~Hz}, \mathrm{H}-$ 4) was presented. Additionally, the presence of multiple protons between $\delta_{\mathrm{H}} 3.20$ and 3.70 and the presence of a doublet at $\delta_{\mathrm{H}}$ $5.12\left(1 \mathrm{H}, \mathrm{d}, J=6.5 \mathrm{~Hz}, \mathrm{H}-1^{\prime}\right)$ suggested the occurrence of a glycose moiety. The ${ }^{13} \mathrm{C}$ NMR spectrum (Table 2) of 4 showed 18 carbons, including a carbonyl carbon at $\delta_{\mathrm{C}} 165.9$ (C-1), a tertiary olefinic carbon at $\delta_{\mathrm{C}} 109.5$ (C-8), a quaternary olefinic carbon at $\delta_{\mathrm{C}} 145.0$ (C-3), six aromatic carbons at $\delta_{\mathrm{C}} 141.4$ (C-3a), 106.4 (C4), 162.8 (C-5), 119.4 (C-6), 126.6 (C-7), and 116.9 (C-7a), and two methylene carbon resonances at $\delta_{\mathrm{C}} 27.4$ (C-9) and 22.0 (C-10). In addition, six oxygenated carbons that contributed to a glycose moiety were also observed at $\delta_{\mathrm{C}} 99.9\left(\mathrm{C}-1^{\prime}\right), 73.1\left(\mathrm{C}-2^{\prime}\right), 76.6$ (C$\left.3^{\prime}\right), 69.5\left(\mathrm{C}-4^{\prime}\right), 77.2\left(\mathrm{C}-5^{\prime}\right)$, and $60.5\left(\mathrm{C}-6^{\prime}\right)$.

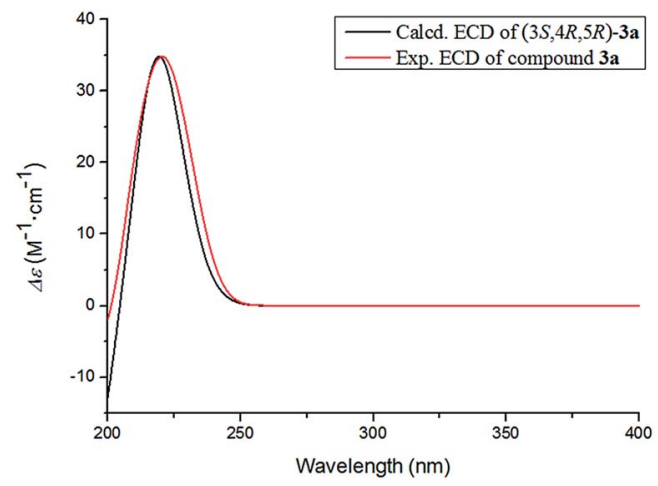

Fig. 6 Experimental ECD and calculated ECD spectrum of $3 a$ in $\mathrm{MeOH}$.
In the HMBC spectrum of 4 , the correlations $\mathrm{H}-7 / \mathrm{C}-1, \mathrm{H}-6 / \mathrm{C}-$ $7 \mathrm{a}, \mathrm{H}-4 / \mathrm{C}-3, \quad \mathrm{H}-8 / \mathrm{C}-3 \mathrm{a}, \mathrm{H}-9 / \mathrm{C}-3, \quad \mathrm{H}-10 / \mathrm{C}-8$ and $\mathrm{H}-11 / \mathrm{C}-9$ confirmed the presence of a butenylphthalide moiety. The glucose moiety was attached at C-5 by the correlation of $\mathrm{H}-1^{\prime} / \mathrm{C}-$ 5. In the NOE experiment, when irradiating $\mathrm{H}-4, \mathrm{H}-8$ generated a gain, and when irradiating the $\mathrm{H}-8, \mathrm{H}-4$ also generated gain signal (ESI $\dagger$ ). Thus the geometric configuration of the double bond was confirmed as $Z$. The glucose was confirmed as having a D-configuration through the same method as used for 3 . The relatively large coupling constant $(J=6.5 \mathrm{~Hz})$ of the anomeric proton suggested that the glucose moiety was $\beta$-configured. Therefore, the structure of $\mathbf{4}$ was established as (Z)-3-butylidene5 -O- $\beta$-D-glucopyranosyl phthalide, named ligusticumside A.

The molecular formula of compound $\mathbf{5}$ was confirmed as $\mathrm{C}_{23} \mathrm{H}_{30} \mathrm{O}_{12}$ by the $[\mathrm{M}-\mathrm{H}]^{-}$ion peak at $m / z 497.1664$ in HRESIMS. The ${ }^{1} \mathrm{H}$ NMR spectrum (Table 2) of 5 presented a methyl resonance at $\delta_{\mathrm{H}} 0.95(3 \mathrm{H}, \mathrm{t}, J=7.5 \mathrm{~Hz}, \mathrm{H}-11)$, two methylene resonances at $\delta_{\mathrm{H}} 1.52(2 \mathrm{H}, \mathrm{m}, \mathrm{H}-10)$ and $2.35(2 \mathrm{H}, \mathrm{m}, \mathrm{H}-9)$ and an olefinic proton at $\delta_{\mathrm{H}} 5.95(1 \mathrm{H}, \mathrm{t}, J=8.0 \mathrm{~Hz}, \mathrm{H}-8)$. An ABX system at $\delta_{\mathrm{H}} 7.83(1 \mathrm{H}, \mathrm{d}, J=8.5 \mathrm{~Hz}, \mathrm{H}-7), 7.23(1 \mathrm{H}, \mathrm{dd}, J=8.5$, $2.0 \mathrm{~Hz}, \mathrm{H}-6)$ and $7.54(1 \mathrm{H}, \mathrm{d}, J=2.0 \mathrm{~Hz}, \mathrm{H}-4)$ was presented. According to the above ${ }^{1} \mathrm{H}$ NMR spectroscopic data, compound 5 had a similar skeleton to $\mathbf{4}$ except for the glycose moiety. The presence of multiple protons between $\delta_{\mathrm{H}} 3.10$ and $\delta_{\mathrm{H}} 3.89$ and the presence of two doublets at $\delta_{\mathrm{H}} 5.10\left(1 \mathrm{H}, \mathrm{d}, J=7.0 \mathrm{~Hz}, \mathrm{H}-1^{\prime}\right)$ and $4.80\left(1 \mathrm{H}, \mathrm{d}, J=3.0 \mathrm{~Hz}, \mathrm{H}-1^{\prime \prime}\right)$ suggested the occurrence of two sugar moieties. Compared with the ${ }^{13} \mathrm{C}$ NMR spectroscopic data of $\mathbf{4}$, compound 5 had an additional five carbons whose resonances at $\delta_{\mathrm{C}} 109.2\left(\mathrm{C}-1^{\prime \prime}\right), 75.9\left(\mathrm{C}-2^{\prime \prime}\right), 78.8\left(\mathrm{C}-3^{\prime \prime}\right), 73.3\left(\mathrm{C}-4^{\prime \prime}\right)$, and $63.1\left(\mathrm{C}-5^{\prime \prime}\right)$ were observed, and combined with the coupling constant $(J=3.0 \mathrm{~Hz})$, the pentose was confirmed to be $\beta$-apiose. The apiose and glucose moieties were further determined to have $\mathrm{D}$-configurations by the above method. The $\beta$-anomeric configuration was deduced on the basis of the coupling constant (Glc: $J=7.0 \mathrm{~Hz}$ ). The connective position of apiose was identified by the correlation of $\mathrm{H}-6^{\prime} / \mathrm{C}-1^{\prime \prime}$, which confirmed that the $\mathrm{C}-1^{\prime \prime}$ of the apiofuranosyl was located at the C-6 $6^{\prime}$ of the glucopyranosyl in the HMBC spectrum. The geometric configuration of the double bond was confirmed as $Z$ by comparison with the data of ${ }^{1} \mathrm{H}$ NMR and ${ }^{13} \mathrm{C}$ NMR in 4 . Thus, compound 5 was established as (Z)-3-butylidene-5-O- $\beta$-D-apiofuranosyl-( $1 \rightarrow$ 6)- $\beta$-D-glucopyranosyl phthalide, named ligusticumside $B$. 
Table $2{ }^{1} \mathrm{H}$ and ${ }^{13} \mathrm{C}$ NMR data of compounds $4-7$ in DMSO $-d_{6}$

\begin{tabular}{|c|c|c|c|c|c|c|c|c|}
\hline \multirow[b]{2}{*}{ Position } & \multicolumn{2}{|l|}{$4^{a}$} & \multicolumn{2}{|l|}{$5^{a}$} & \multicolumn{2}{|l|}{$6^{b}$} & \multicolumn{2}{|l|}{$7^{b}$} \\
\hline & $\delta_{\mathrm{H}}(J$ in $\mathrm{Hz})$ & $\delta_{\mathrm{C}}$ & $\delta_{\mathrm{H}}(J$ in $\mathrm{Hz})$ & $\delta_{\mathrm{C}}$ & $\delta_{\mathrm{H}}(J$ in $\mathrm{Hz})$ & $\delta_{\mathrm{C}}$ & $\delta_{\mathrm{H}}(J$ in $\mathrm{Hz})$ & $\delta_{\mathrm{C}}$ \\
\hline 1 & & 165.9 & & 165.9 & & 165.8 & & 165.8 \\
\hline 3 & & 145.0 & & 144.9 & & 144.9 & & 144.9 \\
\hline $3 \mathrm{a}$ & & 141.4 & & 141.3 & & 141.2 & & 141.2 \\
\hline 4 & $7.59, \mathrm{~d}(2.0)$ & 106.4 & $7.54, \mathrm{~d}(2.0)$ & 106.7 & $7.54, \mathrm{~d}(1.8)$ & 106.6 & $7.54, \mathrm{~d}(1.8)$ & 106.6 \\
\hline 5 & & 162.8 & & 162.7 & & 162.6 & & 162.6 \\
\hline 6 & $7.20, \mathrm{dd}(2.0,8.5)$ & 119.4 & $7.23, \mathrm{dd}(2.0,8.5)$ & 119.1 & 7.23, dd $(1.8,9.0)$ & 119.0 & $7.23, \mathrm{dd}(1.8,8.4)$ & 119.0 \\
\hline 7 & $7.80, \mathrm{~d}(8.5)$ & 126.6 & $7.83, \mathrm{~d}(8.5)$ & 126.7 & $7.82, \mathrm{~d}(9.0)$ & 126.6 & $7.82, \mathrm{~d}(8.4)$ & 126.6 \\
\hline $7 \mathrm{a}$ & & 116.9 & & 117.0 & & 117.0 & & 117.0 \\
\hline 8 & $5.96, \mathrm{t}(8.0)$ & 109.5 & $5.95, \mathrm{t}(8.0)$ & 109.6 & $5.95, \mathrm{t}(7.8)$ & 109.4 & $5.95, \mathrm{t}(7.8)$ & 109.4 \\
\hline 9 & $2.36, \mathrm{q}(7.5)$ & 27.4 & $2.35, \mathrm{~m}$ & 27.4 & $2.36, \mathrm{~m}$ & 27.4 & $2.35, \mathrm{~m}$ & 27.3 \\
\hline 10 & $1.51, \mathrm{~m}$ & 22.0 & $1.52, \mathrm{~m}$ & 22.0 & $1.52, \mathrm{~m}$ & 21.9 & $1.52, \mathrm{~m}$ & 21.9 \\
\hline 11 & $0.95, \mathrm{t}(7.5)$ & 13.8 & $0.95, \mathrm{t}(7.5)$ & 13.8 & $0.95, \mathrm{t}(7.8)$ & 13.7 & $0.95, \mathrm{t}(7.2)$ & 13.7 \\
\hline \multicolumn{9}{|l|}{ Glc } \\
\hline $1^{\prime}$ & $5.12, \mathrm{~d}(6.5)$ & 99.9 & $5.10, \mathrm{~d}(7.0)$ & 99.9 & $5.12, \mathrm{~d}(7.2)$ & 99.8 & $5.11, \mathrm{~d}(7.2)$ & 99.8 \\
\hline $2^{\prime}$ & $3.20, \mathrm{~m}$ & 73.1 & $3.13, \mathrm{~m}$ & 73.1 & $3.29, \mathrm{~m}$ & 73.0 & $3.29, \mathrm{~m}$ & 73.0 \\
\hline $3^{\prime}$ & $3.29, \mathrm{~m}$ & 76.6 & $3.30, \mathrm{~m}$ & 75.6 & $3.30, \mathrm{~m}$ & 75.6 & $3.28, \mathrm{~m}$ & 75.6 \\
\hline $4^{\prime}$ & $3.29, \mathrm{~m}$ & 69.5 & $3.29, \mathrm{~m}$ & 69.8 & $3.16, \mathrm{~m}$ & 69.6 & $3.14, \mathrm{~m}$ & 69.6 \\
\hline $5^{\prime}$ & $3.47, \mathrm{~m}$ & 77.2 & $3.63, \mathrm{~m}$ & 76.5 & $3.63, \mathrm{~m}$ & 76.4 & $3.62, \mathrm{~m}$ & 76.4 \\
\hline \multirow[t]{2}{*}{$6^{\prime}$} & $3.47, \mathrm{~m}$ & 60.5 & $3.43, \mathrm{~m}$ & 67.4 & 3.45 , dd $(6.6,10.8)$ & 67.3 & 3.45 , dd $(6.6,10.8)$ & 67.2 \\
\hline & $3.70, \mathrm{~m}$ & & $3.88, \mathrm{~m}$ & & $3.88, \mathrm{~d}(10.8)$ & & $3.88, \mathrm{~m}$ & \\
\hline \multicolumn{9}{|l|}{ Api-1 } \\
\hline $1^{\prime \prime}$ & & & $4.80, \mathrm{~d}(3.0)$ & 109.2 & $4.80, \mathrm{~d}(3.0)$ & 108.7 & $4.80, \mathrm{~d}(3.0)$ & 108.9 \\
\hline $2^{\prime \prime}$ & & & 3.73, dd $(3.0,6.5)$ & 75.9 & $3.73, \mathrm{dd}(3.0,6.6)$ & 76.1 & 3.69, dd $(3.0,6.6)$ & 76.8 \\
\hline $3^{\prime \prime}$ & & & & 78.8 & & 78.7 & & 77.6 \\
\hline \multirow[t]{2}{*}{$4^{\prime \prime}$} & & & $3.59, \mathrm{~d}(9.0)$ & 73.3 & $3.58, \mathrm{~d}(9.6)$ & 73.4 & $3.64, \mathrm{~m}$ & 73.6 \\
\hline & & & $3.86, \mathrm{~m}$ & & $3.84, \mathrm{~d}(9.0)$ & & $3.86, \mathrm{~m}$ & \\
\hline \multirow[t]{2}{*}{$5^{\prime \prime}$} & & & $3.33, \mathrm{~m}$ & 63.1 & $3.33, \mathrm{~m}$ & 69.1 & $3.36, \mathrm{~d}(9.6)$ & 69.8 \\
\hline & & & & & $3.50, \mathrm{~d}(9.6)$ & & $3.62, \mathrm{~m}$ & \\
\hline \multicolumn{9}{|l|}{ Api-2 } \\
\hline $1^{\prime \prime \prime}$ & & & & & $4.81, \mathrm{~d}(3.6)$ & 109.0 & $4.85, \mathrm{~d}(4.8)$ & 102.1 \\
\hline $2^{\prime \prime \prime}$ & & & & & 3.76, dd $(3.6,6.0)$ & 75.6 & 3.76 , dd $(4.8,9.6)$ & 71.4 \\
\hline $3^{\prime \prime \prime}$ & & & & & & 77.4 & & 76.1 \\
\hline \multirow[t]{2}{*}{$4^{\prime \prime \prime}$} & & & & & $3.60, \mathrm{~m}$ & 73.3 & $3.65, \mathrm{~m}$ & 73.8 \\
\hline & & & & & $3.84, \mathrm{~d}(9.0)$ & & $3.90, \mathrm{~d}(9.6)$ & \\
\hline \multirow[t]{2}{*}{$5^{\prime \prime \prime}$} & & & & & $3.30, \mathrm{~m}$ & 63.1 & $3.23, \mathrm{dd}(5.4,9.6)$ & 63.0 \\
\hline & & & & & $3.33, \mathrm{~m}$ & & $3.28, \mathrm{~m}$ & \\
\hline
\end{tabular}

${ }^{a} 500 \mathrm{MHz}$ for ${ }^{1} \mathrm{H}$ NMR, $125 \mathrm{MHz}$ for ${ }^{13} \mathrm{C}$ NMR. ${ }^{b} 600 \mathrm{MHz}$ for ${ }^{1} \mathrm{H}$ NMR, $150 \mathrm{MHz}$ for ${ }^{13} \mathrm{C}$ NMR.

The molecular formula of 6 was assigned as $\mathrm{C}_{28} \mathrm{H}_{38} \mathrm{O}_{16}$ based on the $[\mathrm{M}+\mathrm{Na}]^{+}$ion peak at $m / z 653.2046$ (calcd 653.2052) in the HRESIMS. By carefully comparing the related data, 6 had similar structural characteristics to $\mathbf{4}$ and $\mathbf{5}$, with the main difference that 6 had a three-monosaccharide unit. In the ${ }^{1} \mathrm{H}$ NMR spectrum (Table 2) of $\mathbf{6}$, the presence of multiple protons between $\delta_{\mathrm{H}}$ 3.15 and $\delta_{\mathrm{H}} 3.89$ and the presence of three anomeric protons at $\delta_{\mathrm{H}} 5.12\left(1 \mathrm{H}, \mathrm{d}, J=7.2 \mathrm{~Hz}, \mathrm{H}-1^{\prime}\right), 4.80\left(1 \mathrm{H}, \mathrm{d}, J=3.0 \mathrm{~Hz}, \mathrm{H}-1^{\prime \prime}\right)$ and $4.81\left(1 \mathrm{H}, \mathrm{d}, J=3.6 \mathrm{~Hz}, \mathrm{H}-1^{\prime \prime \prime}\right)$ suggested the occurrence of three monosaccharide units. The ${ }^{13} \mathrm{C}$ NMR resonances (Table 2) at $\delta_{\mathrm{C}}$ $99.8,108.7$, and 109.0 indicated that 6 had a pyranose and two furanoses. The apiose and glucose were determined to have $\mathrm{D}^{-}$ configurations through the same method as used above. The $\beta$ anomeric configurations were confirmed on the basis of their coupling constants (Glc: $J=7.2 \mathrm{~Hz}$; Api-inner: $J=3.0 \mathrm{~Hz}$; Apiouter: $J=3.6 \mathrm{~Hz}$ ). In the HMBC spectrum, the glucose moiety was also attached at $\mathrm{C}-5$ by the correlation of $\mathrm{H}-\mathrm{1}^{\prime} / \mathrm{C}-5$. The correlation $\mathrm{H}-6^{\prime} / \mathrm{C}-\mathrm{1}^{\prime \prime}$ confirmed that the apiofuranosyl was located at the glucopyranosyl. The correlation $\mathrm{H}-5^{\prime \prime} / \mathrm{C}-\mathbf{1}^{\prime \prime \prime}$ confirmed that the outer apiofuranosyl was located at the inner apiofuranosyl. Thus, compound 6 was established as (Z)-3butylidene-5-O- $\beta$-D-apiofuranosyl-(1 $\rightarrow$ 5)- $\beta$-D-apiofuranosyl-(1 $\rightarrow 6$ )- $\beta$-D-glucopyranosyl phthalide, named ligusticumside $\mathrm{C}$.

Compound 7 had the same molecular formula $\left(\mathrm{C}_{28} \mathrm{H}_{38} \mathrm{O}_{16}\right)$ as 6 through the HRESIMS at $m / z$ 653.2066 $[\mathrm{M}+\mathrm{Na}]^{+}$. A careful comparison of the IR, UV and NMR data of 6 and 7 suggested that they had the same planar structure. The main difference was the chemical shifts of $\mathrm{C}-1^{\prime \prime \prime}$ and $\mathrm{C}-2^{\prime \prime \prime}$ of the outer apiose at $\delta_{\mathrm{C}} 102.1$ and 71.4 in 7, instead of $\delta_{\mathrm{C}} 109.0$ and 75.6 in 6, respectively. This was confirmed by the coupling constant of $\mathrm{H}$ $1^{\prime \prime \prime}(J=4.8 \mathrm{~Hz}$ in $7 v s . J=3.6 \mathrm{~Hz}$ in 6$)$. Clearly, the outer sugar unit had an $\alpha$ configuration instead of the $\beta$ configuration in 6 . 
The sugar moieties were determined to be D-configurations of apiose and glucose through the same method as used above. Therefore, the structure of 7 was confirmed as (Z)-3-butylidene5 - $O$ - $\alpha$-D-apiofuranosyl- $(1 \rightarrow 5)-\beta$-D-apiofuranosyl-(1 $\rightarrow 6)-\beta$-Dglucopyranosyl phthalide, named ligusticumside $\mathrm{D}$.

According to the $[\mathrm{M}+\mathrm{Na}]^{+}$ion peak at $m / z 683.2164$ in the HRESIMS, the molecular formula of $\mathbf{8}$ was assigned as $\mathrm{C}_{29} \mathrm{H}_{40} \mathrm{O}_{17}$. Comparing its NMR data with those of 7 , both of them are trisaccharides of butylidenephthalide with the major difference between them being the type of the outer sugar. The presence of an anomeric proton at $\delta_{\mathrm{H}} 4.64(1 \mathrm{H}, \mathrm{d}, J=3.5 \mathrm{~Hz}, \mathrm{H}-$ $\left.1^{\prime \prime \prime}\right)$ and carbons at $\delta_{\mathrm{C}} 99.2,72.8,72.1,70.0,73.3$, and 60.8 suggested that the outer sugar of 8 was $\alpha$-glucose instead of $\alpha$ apiose in 7. The apiose and glucose were determined to have $\mathrm{D}^{-}$ configurations by the same method as used above. Thus, the structure of 8 was confirmed as (Z)-3-butylidene-5- $O$ - $\alpha$-D-glucopyranosyl-( $1 \rightarrow 5)$ - $\beta$-D-apiofuranosyl-(1 $\rightarrow$ 6)- $\beta$-D-glucopyranosyl phthalide, named ligusticumside E.

The molecular formula of compound 9 was determined to be $\mathrm{C}_{18} \mathrm{H}_{22} \mathrm{O}_{8}$ through HRESIMS ([M+Na $]^{+}$521.1629). The identical data of HRESIMS, IR, and UV suggested that $\mathbf{5}$ and $\mathbf{9}$ were isomers, with the difference being the geometric configuration of the double bond. In the ${ }^{1} \mathrm{H}$ NMR spectrum of 9 (Table 3), an olefinic proton was presented at $\delta_{\mathrm{H}} 5.90(1 \mathrm{H}, \mathrm{t}, J=7.8 \mathrm{~Hz}, \mathrm{H}-8)$. In the NOE experiment, when irradiating $\mathrm{H}-4, \mathrm{H}-8$ did not generate a gain, and when irradiating $\mathrm{H}-8, \mathrm{H}-4$ also did not generate a gain signal, which was entirely different from the results for 5 (ESI $\dagger)$. Additionally, the C-4 $\left(\delta_{\mathrm{C}} 110.1\right)$ and $\mathrm{C}-8\left(\delta_{\mathrm{C}}\right.$ 114.2) were shifted significantly downfield in the ${ }^{13} \mathrm{C}$ NMR spectrum when compared to those of $5\left(\mathrm{C}-4\right.$ at $\delta_{\mathrm{C}} 106.7$ and C-8 at $\delta_{\mathrm{C}}$ 109.6). Thus, the double bond was proven to have an $E$ configuration, and compound 9 was confirmed as (E)-3-butylidene-5- $O$ - $\beta$-D-apiofuranosyl-( $1 \rightarrow 6)-\beta$-D-glucopyranosyl phthalide, named ligusticumside $\mathrm{F}$.

Compound 10 was obtained as a white amorphous powder. The HRESIMS showed a positive ion at $m / z 405.1156[\mathrm{M}+\mathrm{Na}]^{+}$ that matched the molecular formula $\mathrm{C}_{18} \mathrm{H}_{22} \mathrm{O}_{9}$. The IR spectrum presented hydroxyl $\left(3395 \mathrm{~cm}^{-1}\right)$ and $\gamma$-lactone $\left(1757 \mathrm{~cm}^{-1}\right)$ peaks. The ${ }^{1} \mathrm{H}$ NMR spectrum of 10 (Table 3 ) showed three aromatic resonances at $\delta_{\mathrm{H}} 7.27(1 \mathrm{H}, \mathrm{d}, J=8.0 \mathrm{~Hz}, \mathrm{H}-4), 7.54(1 \mathrm{H}$, $\mathrm{t}, J=8.0 \mathrm{~Hz}, \mathrm{H}-5)$, and $6.89(1 \mathrm{H}, \mathrm{d}, J=8.0 \mathrm{~Hz}, \mathrm{H}-6)$, which were assigned to a 1,2,3-trisubstituted benzene ring, an olefinic resonance at $\delta_{\mathrm{H}} 5.86(1 \mathrm{H}, \mathrm{t}, J=7.5 \mathrm{~Hz}, \mathrm{H}-8)$, two methylene resonances at $\delta_{\mathrm{H}} 2.40(2 \mathrm{H}, \mathrm{q}, J=7.5 \mathrm{~Hz}, \mathrm{H}-9)$ and $1.71(2 \mathrm{H}, \mathrm{m}, \mathrm{H}-$ $10)$, and a pair of oxygen-methylene resonances at $\delta_{\mathrm{H}} 3.50(1 \mathrm{H}$, $\mathrm{m}, \mathrm{H}-11 \mathrm{a})$ and $3.83(1 \mathrm{H}, \mathrm{m}, \mathrm{H}-11 \mathrm{~b})$, as well as the glucoside resonances. The ${ }^{13} \mathrm{C}$ NMR experiment (Table 3) presented 18 carbon resonances, including one carbonyl carbon at $\delta_{\mathrm{C}} 164.4$ $(\mathrm{C}-1)$, six aromatic carbons, two olefinic carbons at $\delta_{\mathrm{C}} 145.0(\mathrm{C}-3)$ and $107.9(\mathrm{C}-8)$, two methylene carbon resonances at $\delta_{\mathrm{C}} 22.3(\mathrm{C}-$ 9) and $28.9(\mathrm{C}-10)$, one oxygen-methylene resonance at $\delta_{\mathrm{C}} 68.1$ (C-11), and a set of glucose carbon resonances, implying that $\mathbf{1 0}$ was still a phthalide derivative with a glucose unit. The correlation of $\mathrm{H}-1^{\prime} / \mathrm{C}-11$ in the $\mathrm{HMBC}$ spectrum suggested that the glucose moiety was located at $\mathrm{C}-11$. The glucose was confirmed as having a D-configuration by the same method as used above. The $\beta$-configuration was deduced based on the coupling constant $(J=8.0 \mathrm{~Hz})$ of $\mathrm{H}-\mathbf{1}^{\prime}$. Thus, compound 10 was determined to be (Z)-3-(4-O- $\beta$-D-glucopyranosyl-butylidene)-7hydroxyphthalide, named ligusticumside $\mathrm{G}$.

Compound 11 had the molecular formula $\mathrm{C}_{23} \mathrm{H}_{30} \mathrm{O}_{13}$ by the analysis of its HRESIMS, which gave a positive ion at $\mathrm{m} / \mathrm{z}$ 537.1587 $[\mathrm{M}+\mathrm{Na}]^{+}$(calcd 537.1579). An ABX system at $\delta_{\mathrm{H}} 7.17$ $(1 \mathrm{H}, \mathrm{d}, J=2.0 \mathrm{~Hz}, \mathrm{H}-4), 6.97(1 \mathrm{H}, \mathrm{dd}, J=2.0,8.0 \mathrm{~Hz}, \mathrm{H}-6)$ and $7.68(1 \mathrm{H}, \mathrm{d}, J=8.0 \mathrm{~Hz}, \mathrm{H}-7)$ (Table 3$)$ in the ${ }^{1} \mathrm{H}$ NMR spectrum suggested the presence of the same trisubstituted aromatic ring as in 4 instead of that in 10. In the HMBC experiment, $\mathrm{H}-7\left(\delta_{\mathrm{H}}\right.$ 7.68) correlated with $\mathrm{C}-5\left(\delta_{\mathrm{C}} 163.8\right)$ and $\mathrm{C}-3 \mathrm{a}\left(\delta_{\mathrm{C}} 141.8\right), \mathrm{H}-6\left(\delta_{\mathrm{H}}\right.$ 6.97) correlated with $\mathrm{C}-4\left(\delta_{\mathrm{C}} 114.4\right)$ and C-7a $\left(\delta_{\mathrm{C}} 105.6\right)$, and $\mathrm{H}-4$ $\left(\delta_{\mathrm{H}} 7.17\right)$ correlated with C-6 $\left(\delta_{\mathrm{C}} 118.5\right), \mathrm{C}-7 \mathrm{a}\left(\delta_{\mathrm{C}} 105.6\right)$, and C-3 $\left(\delta_{\mathrm{C}}\right.$ 144.9), indicating that the aromatic hydroxyl was located at position C-5. The additional resonances at $\delta_{\mathrm{H}} 4.84(1 \mathrm{H}, \mathrm{d}$, $J=3.0 \mathrm{~Hz}, \mathrm{H}-1^{\prime \prime}$ ) and from $\delta_{\mathrm{H}} 3.84$ to 3.30 were attributed to one pentose in 11. The ${ }^{13} \mathrm{C}$ NMR spectrum showed 23 carbon resonances (Table 3 ), and the corresponding pentose resonances at $\delta_{\mathrm{C}} 109.2\left(\mathrm{C}-1^{\prime \prime}\right), 75.8\left(\mathrm{C}-2^{\prime \prime}\right), 78.8\left(\mathrm{C}-3^{\prime \prime}\right), 73.4\left(\mathrm{C}-4^{\prime \prime}\right)$, and $63.1(\mathrm{C}-$ $\left.5^{\prime \prime}\right)$ were observed. The apiofuranosyl and glucopyranosyl were determined to have D-configurations by the same method as used above (retention times at 18.26, $29.32 \mathrm{~min}$ ). The coupling constants of the anomeric protons indicated the $\beta$-configuration (Glc: $J=8.0 \mathrm{~Hz}$; Api: $J=3.0 \mathrm{~Hz}$ ). Moreover, the correlation between $\mathrm{H}-1^{\prime \prime}\left(\delta_{\mathrm{H}} 4.84\right)$ and $\mathrm{C}-6^{\prime}\left(\delta_{\mathrm{C}} 68.2\right)$ confirmed that the C$1^{\prime \prime}$ of the apiofuranosyl was located at the C- $6^{\prime}$ of the glucopyranosyl. Thus, compound $\mathbf{1 1}$ was confirmed as $(Z)-3-\left[4-O-\beta-\mathrm{D}^{-}\right.$ apiofuranosyl-(1 $\rightarrow \quad 6)-\beta$-D-glucopyranosyl-butylidene]-7hydroxyphthalide, named ligusticumside $\mathrm{H}$.

Compounds 1-11 were tested for their neuroprotective effects on SH-SY-5Y cell injury induced by $\mathrm{H}_{2} \mathrm{O}_{2}$ and OGD with L-NBP (L-3- $n$-butylphthalide) as a positive control. The results showed that compound $\mathbf{5}$ exhibited a weak neuroprotective effect with the increase cell viability rate of $15.60 \%$ and compound 4 exhibited a moderate neuroprotective effect with the increase cell viability rate of $24.35 \%$, compared with the positive control L-NBP with increase cell viability rate of $18.26 \%$ on $\mathrm{H}_{2} \mathrm{O}_{2}$-induced neurotoxicity. And compound 4 exhibited a moderate neuroprotective effect with the increase cell viability rate of $13.72 \%$, compared with the positive control L-NBP with increase cell viability rate of $4.03 \%$ on OGD-induced neurotoxicity.

\section{Experimental}

\section{General experimental procedures}

The optical rotations, UV spectra and ECD spectra were recorded with JASCO P-2000, V650 and J-815 spectrometer (JASCO, Easton, MD, USA), respectively. The Infrared spectra were measured on Nicolet 5700 spectrometer (Thermo Scientific, FL, USA). The NMR spectra were recorded with Varian $500 \mathrm{MHz}$ (Bruker-Biospin, Billerica, MA, USA) and $600 \mathrm{MHz}$ NMR spectrometers (Varian, Inc., Palo Alto, CA, USA). HRESIMS reports were obtained from Agilent 6520 HPLC-Q-TOF (Agilent Technologies, Waldbronn, Germany) and LCMS-IT-TOF system (Shimadzu Scientific Instruments Inc., Kyoto, Japan). Preparative HPLC was performed using a Shimadzu LC-10AT with 
Table $3{ }^{1} \mathrm{H}$ and ${ }^{13} \mathrm{C}$ NMR data of compounds 8-11 in DMSO- $d_{6}$

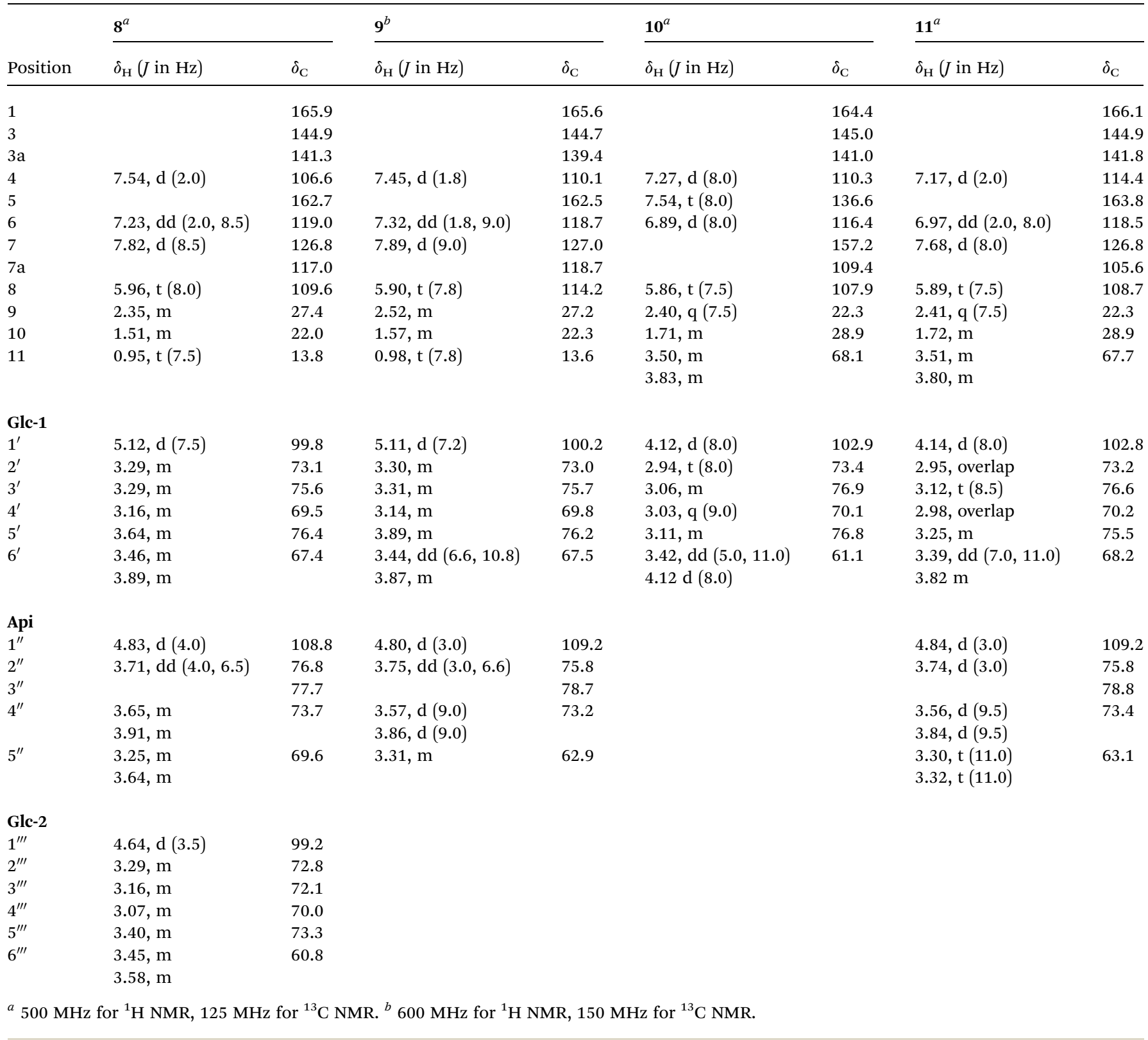

a ODS-A column $(250 \mathrm{~mm} \times 20 \mathrm{~mm}, 5 \mu \mathrm{m}$; YMC Corp., Kyoto, Japan). The Agilent 1200 series system was used to carry on the HPLC-DAD analysis with an Apollo $\mathrm{C}_{18}$ column $(250 \mathrm{~mm} \times 4.6$ $\mathrm{mm}, 5 \mu \mathrm{m}$; Alltech Corp., Lexington, KY, USA). The Agilent 7890A was used to carry on the GC analysis with a capillary column, HP-5 $(60 \mathrm{~m} \times 0.32 \mathrm{~mm}$, with a $1 \mu \mathrm{m}$ film; Agilent Technologies Inc., CA, USA). Macroporous resin Diaion HP-20 (Mitsubishi Chemical Corp., Tokyo, Japan), RP-C 18 (50 $\mu \mathrm{m}$, YMC Corp.), and Sephadex LH-20 (Pharmacia Fine Chemicals, Uppsala, Sweden) were used to column chromatograph.

\section{Plant material}

The roots of Ligusticum chuanxiong Hort. were collected from Pengzhou Town, Sichuan Province in PRC, in Jun 2013 and identified by professor L. Ma. A voucher specimen (ID-S-2594) was deposited at the Institute of Materia Medica, Peking Union Medical College and Chinese Academy of Medical Sciences, Beijing, China.

\section{Extraction and isolation}

The powdered rhizome of $L$. chuanxiong Hort. (100.0 kg) was exhaustively extracted with $80 \% \mathrm{EtOH}$ under reflux condition. The solvent was evaporated by reduced pressure and then the residue $(23.1 \mathrm{~kg})$ was partitioned successively with EtOAc and $n$-BuOH. The $n$-BuOH-soluble portion (1300 g) was applied on a HP-20 column to give five fractions A-E through gradient elution with $\mathrm{H}_{2} \mathrm{O}, 15 \%$ ethanol, $30 \%$ ethanol, $50 \%$ ethanol, and $95 \%$ ethanol, respectively. Fraction C (103.0 g) was 
chromatographed over an $\mathrm{RP}^{-\mathrm{C}_{18}}$ column, eluting with $\mathrm{H}_{2} \mathrm{O}$ / $\mathrm{MeOH}$ (from $100: 0$ to $0: 100$ ) to give 16 fractions (C1-C16) on the basis of HPLC analyses. Fraction C5 was subjected to a Sephadex LH-20 with a gradient of increasing $\mathrm{MeOH}(0-100 \%)$ in $\mathrm{H}_{2} \mathrm{O}$ and then separated by preparative $\mathrm{HPLC}\left(\mathrm{MeOH} / \mathrm{H}_{2} \mathrm{O}\right.$, 30 : 70, V/V, HOAc, $0.01 \%$ ) to give 2 (4 mg). Fraction C13 was separated by column chromatography over a Sephadex LH-20 using $\mathrm{H}_{2} \mathrm{O}$ as the eluent and was further purified by preparative HPLC $\left(\mathrm{MeOH} / \mathrm{H}_{2} \mathrm{O}, 45: 55, \mathrm{v} / \mathrm{v}, \mathrm{HOAc}, 0.01 \%\right)$ to give 1 (64 $\mathrm{mg})$. Compounds $\mathbf{1 0}(4 \mathrm{mg})$ and $\mathbf{1 1}(4 \mathrm{mg})$ were obtained from fraction C14 with the above method. Fraction D (48.0 g) was chromatographed over an $\mathrm{RP}^{-\mathrm{C}_{18}}$ column, eluting with $\mathrm{H}_{2} \mathrm{O}$ / $\mathrm{MeOH}$ (from $95: 5$ to $0: 100$ ) to give 24 fractions (D1-D24) on the basis of HPLC and TLC analyses. Fraction D9 was purified by a Sephadex LH-20 with a gradient of increasing $\mathrm{MeOH}(0-$ $100 \%)$ in $\mathrm{H}_{2} \mathrm{O}$ and then separated by preparative HPLC (MeCN/ $\left.\mathrm{H}_{2} \mathrm{O}, 28: 72, \mathrm{~V} / \mathrm{V}, \mathrm{HOAc}, 0.02 \%\right)$ to give $4(70 \mathrm{mg}), 5(50 \mathrm{mg}), 6$ (3 mg), 7 (4 mg), 8 (3 mg), and 9 (10 mg). Fraction D8 was chromatographed over a Sephadex LH-20 with a gradient of increasing $\mathrm{MeOH}(0-100 \%)$ in $\mathrm{H}_{2} \mathrm{O}$ to give 19 fractions (D8-1D8-19) on the basis of HPLC and TLC analyses. Fraction D8-2 was chromatographed over silica gel (EtOAC/ $\mathrm{MeOH} / \mathrm{H}_{2} \mathrm{O}$, from $120: 1: 0.5$ to $1: 1: 0.5)$ to give $3(120 \mathrm{mg})$.

\section{Structure characterization}

Thiosenkyunolide A, 1 . White amorphous powder; UV $\lambda_{\max }$ $(\mathrm{MeOH})(\log \varepsilon): 201$ (4.01), 277 (4.09) nm; $[\alpha]_{\mathrm{D}}^{20}-49$ (c 0.1 $\mathrm{MeOH}$ ); HRESIMS $\mathrm{m} / \mathrm{z} 345.0999[\mathrm{M}+\mathrm{H}]^{+}$(calcd 345.1003), $\mathrm{m} / \mathrm{z}$ $367.0823[\mathrm{M}+\mathrm{Na}]^{+}$(calcd 367.0822); IR (KBr) $\nu_{\text {max }}: 3387,2938$, 1741, 1682, 1633, 1514, 1414, 1230, 1184, 1093, 1043, $954 \mathrm{~cm}^{-1}$; ${ }^{1} \mathrm{H}$ NMR and ${ }^{13} \mathrm{C}$ NMR see Table 1.

Thiosenkyunolide $\mathbf{B}, 2$. White amorphous powder; UV $\lambda_{\max }$ $(\mathrm{MeOH})(\log \varepsilon): 201$ (3.84), $277(4.06) \mathrm{nm} ;[\alpha]_{\mathrm{D}}^{20}+30(c 0.1 \mathrm{MeOH})$; HRESIMS $m / z 345.1008[\mathrm{M}+\mathrm{H}]^{+}$(calcd 345.1003), $\mathrm{m} / z 367.0827$ $[\mathrm{M}+\mathrm{Na}]^{+}$(calcd 367.0822); IR (KBr) $\nu_{\text {max }}: 3347,2932,2882,1756$, 1680, 1632, 1412, 1323, 1239, 1090, 1048, 1026, 997, $966 \mathrm{~cm}^{-1}$; ${ }^{1} \mathrm{H}$ NMR and ${ }^{13} \mathrm{C}$ NMR see Table 1.

Ligusticoside $\mathbf{B}, 3$. White amorphous powder; UV $\lambda_{\max }$ $(\mathrm{MeOH})(\log \varepsilon): 203$ (4.18), $216(3.90) \mathrm{nm} ;[\alpha]_{\mathrm{D}}^{20}+4(c 0.1 \mathrm{MeOH})$; HRESIMS $m / z$ 503.2148 [M - H] $]^{-}$(calcd 503.2134); IR (KBr) $\nu_{\text {max }}$ : 3336, 2924, 1774, 1275, 1350, $1049 \mathrm{~cm}^{-1} ;{ }^{1} \mathrm{H}$ NMR and ${ }^{13} \mathrm{C}$ NMR see Table 1.

Ligusticumside A, 4. White amorphous powder; UV $\lambda_{\max }$ $(\mathrm{MeOH})(\log \varepsilon): 253$ (4.42), 273 (4.16) nm; $[\alpha]_{\mathrm{D}}^{20}-73$ (c 0.1 $\mathrm{MeOH}$ ); HRESIMS $\mathrm{m} / \mathrm{z} 367.1399[\mathrm{M}+\mathrm{H}]^{+}$(calcd 367.1387); IR (KBr) $\nu_{\text {max }}:$ 3377, 2929, 1759, 1689, 1613, 1484, 1297, 1078, 991 $\mathrm{cm}^{-1} ;{ }^{1} \mathrm{H}$ NMR and ${ }^{13} \mathrm{C}$ NMR see Table 2 .

Ligusticumside B, 5. White amorphous powder; UV $\lambda_{\max }$ $(\mathrm{MeOH})(\log \varepsilon): 253$ (4.35), 274 (4.07) nm; $[\alpha]_{\mathrm{D}}^{20}-96$ (c 0.1 $\mathrm{MeOH})$; HRESIMS $m / z$ 497.1664 [M - H] ${ }^{-}$(calcd 497.1665); IR (KBr) $\nu_{\max }: 3406,2931,1763,1611,1482,1293,1066,1011 \mathrm{~cm}^{-1}$; ${ }^{1} \mathrm{H}$ NMR and ${ }^{13} \mathrm{C}$ NMR see Table 2 .

Ligusticumside $\mathbf{C}, \mathbf{6}$. White amorphous powder; UV $\lambda_{\max }$ $(\mathrm{MeOH})(\log \varepsilon): 252$ (4.19), 275 (3.92) nm; $[\alpha]_{\mathrm{D}}^{20}-78$ (c 0.1 $\mathrm{MeOH}$ ); HRESIMS $\mathrm{m} / z$ 653.2046 $[\mathrm{M}+\mathrm{Na}]^{+}$(calcd 653.2052); IR
$(\mathrm{KBr}) \nu_{\max }: 3372,2930,1762,1681,1611,1387,1293,1066$, $930 \mathrm{~cm}^{-1} ;{ }^{1} \mathrm{H}$ NMR and ${ }^{13} \mathrm{C}$ NMR see Table 2 .

Ligusticumside $\mathbf{D}, 7$. White amorphous powder; UV $\lambda_{\max }$ $(\mathrm{MeOH})(\log \varepsilon): 253$ (4.27), 272 (4.03) nm; $[\alpha]_{\mathrm{D}}^{20}-30$ (c 0.1 $\mathrm{MeOH}$ ); HRESIMS $m / z$ 653.2066 [M + Na $]^{+}$(calcd 653.2052); IR (KBr) $\nu_{\max }: 3398,2932,1765,1687,1613,1295,1072,930 \mathrm{~cm}^{-1}$; ${ }^{1} \mathrm{H}$ NMR and ${ }^{13} \mathrm{C}$ NMR see Table 2.

Ligusticumside $\mathbf{E}, \mathbf{8}$. White amorphous powder; UV $\lambda_{\max }$ $(\mathrm{MeOH})(\log \varepsilon): 253$ (4.38), 270 (4.16) nm; $[\alpha]_{\mathrm{D}}^{20}-29$ (c 0.1 $\mathrm{MeOH}$ ); HRESIMS $\mathrm{m} / \mathrm{z}$ 683.2164 [M $+\mathrm{Na}]^{+}$(calcd 683.2158); IR (KBr) $\nu_{\max }: 3384,2926,1762,1688,1614,1294,1073,928 \mathrm{~cm}^{-1}$; ${ }^{1} \mathrm{H}$ NMR and ${ }^{13} \mathrm{C}$ NMR see Table 3 .

Ligusticumside F, 9. White amorphous powder; UV $\lambda_{\max }$ $(\mathrm{MeOH})(\log \varepsilon): 254$ (4.08), 272 (3.91) nm; $[\alpha]_{\mathrm{D}}^{20}-21$ (c 0.1 $\mathrm{MeOH}$ ); HRESIMS $m / z 521.1629[\mathrm{M}+\mathrm{Na}]^{+}$(calcd 521.1629); IR (KBr) $\nu_{\text {max }}: 3399,2931,1765,1689,1612,1483,1294,1072,953$ $\mathrm{cm}^{-1} ;{ }^{1} \mathrm{H}$ NMR and ${ }^{13} \mathrm{C}$ NMR see Table 3.

Ligusticumside G, 10. White amorphous powder; UV $\lambda_{\max }$ (MeOH) (log $\varepsilon): 198$ (3.96), 225 (4.14), 265 (3.95), 330 (3.66), 339 (3.70) $\mathrm{nm} ;[\alpha]_{\mathrm{D}}^{20}-10(c 0.1 \mathrm{MeOH})$; HRESIMS $m / z$ 405.1156 [M + $\mathrm{Na}^{+}$(calcd 405.1156); IR (KBr) $\nu_{\text {max }}: 3395,2928,2880,1757$, 1687, 1606, 1473, 1372, 1297, 1199, 1163, 1079, 1017, $895 \mathrm{~cm}^{-1}$; ${ }^{1} \mathrm{H}$ NMR and ${ }^{13} \mathrm{C}$ NMR see Table 3 .

Ligusticumside $\mathbf{H}, \mathbf{1 1}$. White amorphous powder; UV $\lambda_{\max }$ $(\mathrm{MeOH})(\log \varepsilon): 254(4.54) \mathrm{nm} ;[\alpha]_{\mathrm{D}}^{20}-30(c 0.1 \mathrm{MeOH})$; HRESIMS $m / z 537.1587[\mathrm{M}+\mathrm{Na}]^{+}$(calcd 537.1579); IR (KBr) $\nu_{\text {max }}: 3375$, 2932, 2884, 1753, 1689, 1610, 1481, 1467, 1381, 1295, 1165, 1057, 999, $932 \mathrm{~cm}^{-1} ;{ }^{1} \mathrm{H}$ NMR and ${ }^{13} \mathrm{C}$ NMR see Table 3.

\section{Determination of the absolute configuration of sugar}

Compounds 5 ( $2 \mathrm{mg}$ ) was dissolved in $1 \mathrm{~mol} \mathrm{~L}^{-1} \mathrm{CF}_{3} \mathrm{COOH}(14$ $\mathrm{mL}$ ) and then the mixture was heated in $70{ }^{\circ} \mathrm{C}$ for $1 \mathrm{~h}$. The mixture was then extracted three times with EtOAc, and the aqueous layer was freeze-dried to obtain residue. Using the same method with the literature, ${ }^{38}$ the residue was dissolved in anhydrous pyridine $(2 \mathrm{~mL})$, L-cysteine methyl ester hydrochloride $(4 \mathrm{mg}$ ) was added, and then the mixture was heated in a water bath $\left(60^{\circ} \mathrm{C}\right)$ for $1 \mathrm{~h}$. After the reaction solution was dried under vacuum, $N$-trimethylsilylimidazole $(1 \mathrm{~mL})$ was added, and the solution was heated in a water bath $\left(60^{\circ} \mathrm{C}\right)$ for $1 \mathrm{~h}$ and extracted three times with $\mathrm{H}_{2} \mathrm{O} / n$-hexane. Then, the $n$-hexane layer was analyzed using GC under conditions as follows: injection temperature, $300{ }^{\circ} \mathrm{C}$; detector temperature (FID), $300{ }^{\circ} \mathrm{C}$; capillary column, HP-5 $(30 \mathrm{~m} \times 0.32 \mathrm{~mm}$, Dikma); start temperature, $200{ }^{\circ} \mathrm{C}$, raised to $260{ }^{\circ} \mathrm{C}$ at a rate of $10{ }^{\circ} \mathrm{C} \mathrm{min}{ }^{-1}$, and the final temperature maintained for $30 \mathrm{~min}$; and $\mathrm{N}_{2}$ used as the carrier gas.

\section{Neuroprotective activities of compounds 1-11}

The assay method of neuroprotective effects about compounds refer to the procedures of literature. ${ }^{39}$

\section{Conclusions}

In the course of a search for neuroprotective compounds from Ligusticum chuanxiong Hort., eleven new phthalide derivatives 
were obtained. Among them, two are substituted with the rare mercaptopropionic acid. All compounds were tested for their neuroprotective effects, and it was observed that compound 4 had moderate effect against $\mathrm{H}_{2} \mathrm{O}_{2}$ and OGD-induced neurotoxicity in SH-SY5Y cells at $10 \mu \mathrm{M}$. These results could contribute to the better understanding of the therapeutic usage of Ligusticum chuanxiong Hort.

\section{Acknowledgements}

This work was supported by the CAMS Innovation Fund for Medical Sciences (CIFMS) (No. 2016-I2M-1-010).

\section{References}

1 Editing Group for The Compilation of Chinese Herbal Medicines, The Compilation of Chinese Herbal Medicines, People's Medical Publishing House, Beijing, 1996, pp. 133135.

2 J. Huang, X. Q. Lu, C. Zhang, J. Lu, G. Y. Li, R. C. Lin and J. H. Wang, Fitoterapia, 2013, 91, 21-27.

3 C. P. Miao, S. H. Wu, B. Z. Luo, J. Wang and Y. W. Chen, Fitoterapia, 2010, 81, 1088-1090.

4 M. Kim, S. O. Kim, M. Lee, J. H. Lee, W. S. Jung, S. K. Moon, Y. S. Kim, K. H. Cho, C. N. Ko and E. H. Lee, Eur. J. Pharmacol., 2014, 740, 504-511.

5 S. L. Li, S. S. K. Chan, G. Lin, L. Ling, R. Yan, H. S. Chung and Y. K. Tam, Planta Med., 2003, 69, 445-451.

6 N. Y. Yang, D. C. Ren, J. A. Duan, X. H. Xu, N. Xie and L. J. Tian, Helv. Chim. Acta, 2009, 92, 291-297.

7 L. S. Lim, P. Shen, Y. H. Gong and E. L. Yong, Phytochemistry, 2006, 67, 728-734.

8 J. Huang, X. Q. Lu, J. Lu, G. Y. Li, H. Y. Wang, L. H. Li, R. C. Lin and J. H. Wang, J. Asian Nat. Prod. Res., 2013, 15, 1237-1242.

9 Y. H. Li, S. L. Peng, Y. Zhou, K. B. Yu and L. S. Ding, Planta Med., 2006, 72, 652-656.

10 T. Naito, T. Katsuhara, K. Niitsu, Y. Ikeya, M. Okada and H. Mitsuhashi, Phytochemistry, 1992, 31, 639-642.

11 T. Naito, K. Niitsu, Y. Ikeya, M. Okada and H. Mitsuhashi, Phytochemistry, 1992, 31, 1787-1789.

12 T. Naito, Y. Ikeya, M. Okada, H. Mitsuhashi and M. Maruno, Phytochemistry, 1996, 41, 233-236.

13 J. Yang, X. L. Feng, Y. Yu, Q. Wang, J. Zou, C. X. Wang, Z. Q. Mu, X. S. Yao and H. Gao, China's Med., 2016, 11, 1-7.

14 W. Wei, W. Xu and X. W. Yang, J. Asian Nat. Prod. Res., 2017, 19, 704-711.

15 P. O. Donkor, Y. Chen, L. Q. Ding and F. Qiu, J. Ethnopharmacol., 2016, 194, 530-548.

16 X. L. Chang, Z. Y. Jiang, Y. B. Ma, X. M. Zhang, K. W. K. Tsim and J. J. Chen, J. Asian Nat. Prod. Res., 2009, 11, 805-810.
17 M. J. Liang, L. C. He and G. D. Yang, Life Sci., 2005, 78, 128133.

18 E. Y. Kim, J. H. Kim and M. R. Rhyu, Biol. Pharm. Bull., 2010, 33, 1360-1363.

19 K. N. Nam, K. P. Kim, K. H. Cho, W. S. Jung, J. M. Park, S. Y. Cho, S. K. Park, T. H. Park, Y. S. Kim and E. H. Lee, Cell Biochem. Funct., 2013, 31, 707-712.

20 X. Yang, Y. C. Wang, L. L. Li, Y. C. Jin, L. Sironi, Y. Wang and Y. Wang, Fitoterapia, 2014, 95, 240-246.

21 W. Li, S. Zhang, Q. H. Gao, J. W. Hou and T. T. Wei, Res. Chem. Intermed., 2004, 30, 605-613.

22 T. F. Lee, Y. L. Lin and Y. T. Huang, Planta Med., 2007, 73, 527-534.

23 H. Y. Qi, S. O. Siu, Y. Chen, Y. F. Han, I. K. Chu, Y. Tong, A. S. Y. Lau and J. H. Rong, Chem.-Biol. Interact., 2010, 183, 380-389.

24 L. Liu, Z. Q. Ning, S. Shan, K. Zhang, T. Deng, X. P. Lu and Y. Y. Cheng, Planta Med., 2005, 71, 808-813.

25 W. C. Ko, C. C. Liao, C. H. Shih, C. B. Lei and C. M. Chen, Planta Med., 2002, 68, 1004-1009.

26 J. W. Tian, F. H. Fu, W. L. Jiang, C. Y. Wang, F. Sun and T. P. Zhang, China J. Chin. Mater. Med., 2005, 30, 466-468.

27 W. X. Gong, Y. Z. Zhou, X. Li, X. X. Gao, J. S. Tian, X. M. Qin and G. H. Du, Molecules, 2016, 21, 549.

28 T. F. Lee, Y. L. Lin and Y. T. Huang, Planta Med., 2007, 73, 527-534.

29 Y. L. Lin, T. F. Lee, Y. J. Huang and Y. T. Huang, J. Gastroenterol. Hepatol., 2006, 21, 1257-1265.

30 Y. Sim and S. Shin, Arch. Pharmacal Res., 2008, 31, 497-502.

31 X. Kuang, J. R. Du, Y. X. Liu, G. Y. Zhang and H. Y. Peng, Pharmacol., Biochem. Behav., 2008, 88, 213-221.

32 J. Wang, J. R. Du, Y. Wang and C. Y. Wang, Acta Pharmacol. Sin., 2010, 31, 791-797.

33 J. R. Du, B. Bai, X. Kuang, Y. Yu, C. Y. Wang, Y. Ke, Y. J. Xu, A. H. C. Tzang and Z. M. Qian, J. Ethnopharmacol., 2006, 108, 54-58.

34 Q. Lu, T. Q. Qiu and H. Yang, Eur. J. Pharmacol., 2006, 542, 136-140.

35 X. Ran, L. Ma, C. Peng, H. Zhang and L. P. Qin, Pharm. Biol., 2011, 49, 1180-1189.

36 W. Wei, X. W. Wu and X. W. Yang, RSC Adv., 2016, 6, 6103761046.

37 G. Snatzke, U. Wagner and H. P. Wolff, Tetrahedron, 1981, 37, 349-361.

38 M. L. Gan, M. T. Liu, L. S. Gan, S. Lin, B. Liu, Y. L. Zhang, J. C. Zi, W. X. Song and J. G. Shi, J. Nat. Prod., 2012, 75, 1373-1382.

39 S. W. Huang, J. W. Qiao, X. Sun, P. Y. Gao, L. Z. Li, Q. B. Liu, B. Sun, D. L. Wu and S. J. Song, J. Funct. Foods, 2016, 24, 183195. 